\title{
RELASI ISLAM, NEGARA, DAN PANCASILA DALAM PERSPEKTIF TATA HUKUM INDONESIA ${ }^{1}$
}

\author{
Hamdan Zoelva \\ Mahkamah Agung Republik Indonesia \\ Program Magister Ilmu Hukum Universitas Islam As-Syafi'iyah Jakarta \\ email: hamdanzoelva@yahoo.com
}

\begin{abstract}
Abstrak
There are differences of opinion in looking at the relationship between religion and state. Some proposed that the state should be based on religion (Islam) and others have argued the opposite, the state should be separated from the religion (secular nationalism). The debate is considered complete after the Jakarta Charter formula was agreed, although it was annulled after the legalization of the Constitution on August 18, 1945. History shows that Muslims sacrifice for this country is invaluable both in terms of physical struggle (body and soul) and ideological (Islamic values). So that, returning authority to the Muslim community to determine the direction of development of the country has become a necessity. Through this article, the author would like to express a new form of moral calling on Muslims to contribute to this country, some of them with sincerity impose Islamic law into national law.

Terdapat perbedaan pendapat dalam memandang hubungan agama dan negara. Ada yang berpendapat negara harus berdasarkan pada agama (Islam) dan ada yang berpendapat sebaliknya, bahwa negara harus dipisah dari agama (nasionalisme sekuler). Perdebatan dianggap selesai setelah disepakati rumusan Piagam Jakarta, meskipun kemudian dianulir setelah disahkannya UUD tanggal 18 Agustus 1945. Sejarah ini menunjukkan bahwa pengorbanan umat Islam untuk negeri ini tidak ternilai harganya baik ditinjau dari segi perjuangan fisik (jiwa raga) maupun ideologis (nilai-nilai keislaman). Dari pengorbanan tersebut, mengembalikan kewenangan kepada umat Islam untuk menentukan arah pembangunan negara ini menjadi keniscayaan. Karena itu melalui tema ini, penulis ingin mengungkapkan bentuk baru panggilan moral umat Islam untuk memberikan konstribusi terhadap negeri ini, yaitu diantaranya melalui keikhlasan memberlakukan hukum Islam ke dalam hukum nasional.
\end{abstract}

Kata Kunci: Islam, Negara, Nasionalisme

Menguraikan hubungan antara agama dan negara bukanlah pekerjaan yang mudah. Jalinan hubungannya telah memancing perdebatan yang sangat dinamis dalam ketatanegaraan Indonesia. Pokok soal yang sering diperdebatkan adalah keberadaan posisi agama dalam hubungan dengan negara, dalam hal ini termasuk keberadaan hukum agama (hukum Islam) dalam tata hukum Indonesia. Sejauh yang dapat ditangkap dari perjalanan sejarah, perdebatan tersebut telah dimulai sejak awal kemerdekaan, pada masa pembentukan negara bangsa, tatkala para pendiri negara kita (the founding fathers and mathers) dihadapkan pada

\footnotetext{
${ }^{1}$ Materi disampaikan pada Seminar Nasional "Islam, Negara dan Pancasila" diselenggarakan oleh Fakultas Syariah Universitas Islam Negeri Maulana Malik Ibrahim, Malang, 29 November 2012.
} 
persoalan prinsipil, yakni di atas dasar apa negara Indonesia didirikan dan dioperasikan kelak. Dalam hal ini terdapat dua kutub pandangan yang berbeda secara diametral, yaitu negara yang harus berdasarkan agama (Islam) dan negara yang berdasarkan nasionalisme sekuler. Perdebatan itu dianggap selesai ketika disepakati rumusan Jakarta Charter (Piagam Jakarta 22 Juni 1945). Kemudian kompromi yang dianggap sementara, dilakukan ketika pengesahan UUD pada 18 Agustus 1945 dari Piagam Jakarta, yaitu yang menghapuskan tujuh kata "dengan kewajiban menjalankan syari'at Islam bagi pemeluk-pemeluknya". Kesepakatan ini menyimpan bara perdebatan pada masa selanjutnya. Karena kesepakatan pada 18 Agustus 1945 itu dianggap sebagai kesepakatan sementara agar tidak menghambat Indonesia yang baru sehari merdeka

Pada periode ketatanegaraan berikutnya dialektika ini kian berkembang. Ketika tatanan negara berdasarkan kesepakatan 18 Agustus 1945 telah berproses, persentuhan antara agama dan negara faktanya sering berjalan secara dikotomis, dan sering tidak sinergis sehingga menghasilkan hubungan yang bersifat antagonistik sekaligus akomodatif. Masa persidangan konstituante 1957-1959 dianggap gagal mengesahkan konstitusi baru karena persoalan hubungan antara agama (Islam) dan negara ini. Demikian juga pada masa Orde Baru, agama dalam hal ini ditempatkan vis-a-vis dengan negara, sebagaimana tercermin dari kebijakan asas tunggal Pancasila bagi semua organisasi massa dan organisasi politik yang banyak mendapat kecaman dan kritikan tajam. Namun pada saat yang sama, aspirasi keagamaan mendapat tempat dalam tata perundangan dan hukum. Dengan kata lain, hukum agama (Islam) justru tetap diakomodasi dalam tata hukum nasional, bahkan jauh lebih baik dari masa sebelumnya. Fenomena ini kian nampak ketika Indonesia memasuki masa reformasi. Dalam hal ini, hukum Islam mengalami perkembangan se- cara berkesinambungan, baik melalui jalur infrastruktur politik maupun suprastruktur politik. Indikator yang mencerminkan kecenderungan tersebut dapat dilihat dari lahirnya sejumlah perundang-undangan yang dalam ketentuan-ketentuannya menyerap jiwa dan prinsip-prinsip hukum Islam, bahkan banyak undang-undang Islam dilahirkan. Kecenderungan yang paling signifikan nampak dalam bentuk transplantasi hukum Islam ke dalam hukum pidana Indonesia seperti yang diterapkan di Nanggroe Aceh Darussalam (NAD). Hal ini kemudian diikuti oleh pemerintah daerah lainnya dengan sejumlah peraturan daerah yang bernuansa syari'ah.

Hanya saja, pemberlakukan hukum Islam sebagai hukum formal tersebut telah menimbulkan perdebatan publik yang luas. Banyak pertanyaan mengenai formalisasi hukum Islam tersebut baik dari sisi efektivitas maupun penerapannya dalam bingkai negara bangsa Indonesia.Terlebih, muncul kekhawatiran akan terjadi diskriminasi dalam pemberlakukan hukum agama dalam negara Indonesia. Secara politik hal ini dianggap dapat membuka arena konstetasi antar agama di satu pihak, dan antar agama dan negara di pihak lain. Apakah memang demikian? Lantas bagaimana seharusnya hubungan agama dan negara itu dibangun dalam kerangka yang lebih ideal dan konstitusional. Tulisan singkat ini akan menguraikan perkembangan dialektika agama (Islam) dan negara dalam sejarah ketatanegaraan Indonesia, khususnya pada saat proses pembentukan UUD dan pasca perubahannya, serta pengaruh antar kedua pranata tersebut dalam tata hukum Indonesia baik secara praktis maupun empiris. Realita apa saja yang mencuat, dan bagaimana hubungan antar agama dan negara dilembagakan. Pembahasan menyangkut agama (khususnya Islam) dan negara dalam tulisan ini hanya akan difokuskan pada wujud yang melembaga, yakni nilai-nilai hukum Islam yang telah dikongkretkan dan diterapkan dalam ranah ketatanegaraan. 


\section{Dialektika Islam dan Negara dalam Tinjauan Sejarah Indonesia}

Secara historis, dialektika agama dan negara sebenarnya sudah berlangsung lama, jauh sebelum kolonialisasi mengakar di Indonesia. Dalam hal ini, Islam telah berakar dalam kesadaran hukum masyarakat dan mempunyai pengaruh yang bersifat normatif dalam kebudayaan Indonesia. ${ }^{1}$ Ketika Belanda sampai di Nusantara sekitar abad 16-17 Masehi, mereka menemukan beberapa kerajaan besar atau kecil yang tersebar di berbagai pelosok nusantara telah memberlakukan hukum Islam dan corak pemerintahan Islam. Intinya, secara politik raja-raja di nusantara memberlakukan hukum Islam meski tidak dalam konteks peraturan atau perundang-undangan kerajaan. ${ }^{2}$ Namun dalam perkembangan selanjutnya, hukum Islam kian berada dalam posisi yang tidak pasti dan terpinggirkan, karena terdorong oleh kepentingan kolonialisme pada saat itu. Sejak rezim kolonial Belanda menguasai kepulauan Indonesia seutuhnya, politik hukum pun berubah secara sistematis. Pemerintah kolonial Belanda berupaya melakukan pembatasan keberlakuan hukum Islam yang antara lain didasarkan pada teori resepsi3 ${ }^{3}$ yang digagas Snouck Hurgronje dengan pemberlakuan Staatsblad 1937 no. $116^{4}$ Lemahnya posisi hukum Islam ini terus terjadi hingga menjelang berakhirnya kekuasaan Hindia Belanda pada tahun 1942. Demikian halnya pada masa pendudukan Jepang. Meski tidak ada perubahan berarti bagi posisi agama, Islam, selama masa ini, namun dapat dikatakan lebih

\footnotetext{
'Selengkapnya lihat Muhammad Daud Ali, Pengantar Ilmu Hukum dan Tata Hukum Islam di Indonesia, Jakarta: Rajawali Press, 2009, h.223; dan lihat pula Roeslan Abdul Gani, Sejarah Perkembangan Islam di Indonesia, Jakarta: Antar Kota, 1983, h. 27.

${ }^{2}$ Hamka, Sejarah Umat Islam, Bukit Tinggi: N.V. Nusantara, 1961, h. 20.

${ }^{3}$ Hukum Islam baru berlaku bila dikehendaki atau diterima oleh hukum adat.

${ }^{4}$ Aturan ini memuat rekomendasi tidak diterimanya hukum kewarisan islam, dicabutnya wewenang peradilan agama, ditempatkannya pengadilan agama di bawah pengawasan landraad dan putusan pengadilan agama tidak dapak dilaksanakan tanpa executoir Ketua landraad. Lihat M. Yahya Harahap, "Informasi Kompilasi Hukum Islam: Mempositifkan Abstraksi Hukum Islam" dalam Cik Hasan Bisri, Kompilasi Hukum Islam dan Peradilan Agama dalam Sistem Hukum Nasional, Jakarta: Logos, 1999, h. 27.
}

baik dari rezim sebelumnya, karena beberapa badan atau komite bentukan Jepang seperti BPUPKI, duduk tokoh-tokoh yang mewakili kelompok Islam. Ada kehendak Jepang merangkul ummat Islam untuk kepentingan Perang Asia Timur Raya.

Masa Indonesia merdeka adalah saat paling penting dalam sejarah ketatanegaraan Indonesia, dengan semangat membawa perubahan nilai-nilai revolusioner dalam tata hukum di Indonesia, termasuk perjuangan para tokohnya dalam menjadikan hukum Islam sebagai dasar tata hukum Indonesia. Ketika UUD 1945 akan disahkan, dialektika mengenai relasi agama dan negara menjadi awal perdebatan yang menguras energi. Waktu itu ada perbedaan pandangan yang cukup tajam diantara para founding fathers yaitu, antara faksi Islam dan faksi nasionalis dalam sidang BPUPKI. Faksi Islam menghendaki negara berdasar Islam, sedangkan faksi nasionalis menginginkan negara yang tidak berdasarkan agama. ${ }^{5}$ Faksi Islam berprinsip bahwa agama, dalam hal ini Islam, tidak dapat dipisahkan dari urusan kenegaraan, karena agama tidak hanya mengatur hubungan antara manusia dengan Tuhan saja, melainkan juga hubungan sesama manusia, lingkungan dan alam semesta. ${ }^{6}$ Sedangkan faksi nasionalis berprinsip bahwa agama dan negara harus dipisahkan secara tegas dan proporsional, dengan keyakinan bahwa fungsi agama hanya mengurusi ajaran-ajaran yang berkaitan dengan kehidupan akhirat dan urusan pribadi saja, sementara negara memang merupakan masalah politik yang berurusan dengan duniawi. ${ }^{7}$ Sekalipun proses perdebatan mengenai pilihan dasar negara sangat keras, perdebatan itu berakhir pada suatu titik kompromi atau kesepakatan (concensus) yang dituangkan dalam Piagam Jakarta yang dimaksudkan sebagai rancangan Pembukaan UUD, tanggal 22 Juni 1945. Prinsipnya, piagam

\footnotetext{
${ }^{5}$ Lihat Muhammad Yamin, Naskah Persiapan Undang-Undang Dasar 1945. Jakarta: Yayasan Prapanca, 1959, Naskah I, h. 15.

${ }^{6}$ Anders Uhli, Oposisi Berserak, Arus Deras Demokratisasi Gelombang Ketiga di Indonesia, Cet. 2., Bandung: Mizan, 1998, h. 32.

${ }^{7}$ LihatMasykuriAbdillah, DemokrasidiPersimpangan: Respon Intelektual Muslim Indonesia Terhadap Konsep Dmeokrasi, Yogyakarta: Tiara Wacana, 1999, h. 227.
} 
ini merupakan gentleman's agreement ${ }^{8}$ atau social contract $t^{9}$ dari wakil-wakil yang ada dalam forum penyusunan UUD tersebut.

Formulasi resmi pertama Pancasila terdapat dalam Piagam Jakarta, yang sila pertamanya adalah "ketuhanan dengan kewajiban menjalankan syar'iat Islam bagi pemeluk-pemeluknya". Konsekuensinya, kalimat tersebut juga dicantumkan dalam Pasal 29 ayat (1) UUD 1945 dan adanya ketentuan yang mengharuskan Presiden orang Indonesia asli dan beragama Islam. Di sini, nampak kedudukan hukum Islam disebutkan secara ekplisit dan mempunyai posisi yang kuat sebagai cita hukum (rechtsidee). Ini berbeda dengan masa sebelumnya. Pada zaman Belanda, hukum Islam secara sistematik direduksi dengan diberlakukannya hukum adat bagi golongan bumi putera dan hukum barat bagi golongan Eropa. Politik hukum tersebut didasarkan pada teori resepsi atau teori konflik Snouck Hourgronje sebagaimana yang telah disebutkan diatas. Sehingga menurut Hazairin, ${ }^{10}$ adalah reaksi yang wajar dari pihak Islam untuk merehabilitasi hidup keagamaannya melalui "tujuh kata" di Piagam Jakarta. Namun, kompromi yang tertuang dalam Piagam Jakarta itu diformulasikan kembali pada tanggal 18 Agustus 1945 dalam sidang PPKI, dengan alasan kekhawatiran kalangan rakyat Indonesia Timur terhadap kandungan yang ada dalam Piagam Jakarta. Alhasil, "tujuh kata" dalam Piagam Jakarta dihilangkan menjadi "Ketuhanan Yang Maha Esa".

Kendati tanpa memuat delapan kata dari Piagam Jakarta, prinsip Ketuhanan Yang Maha Esa tetap mempertegas bahwa ada hubungan yang tidak dapat dipisahkan antara negara dan agama dalam bangunan ideal negara Indonesia di cita-citakan. Dalam posisi demikian, Negara Republik Indonesia tidak mengenal doktrin pemisahan antara agama dan negara.

\footnotetext{
${ }^{8}$ Lihat selengkapnya dalam Yusril Ihza Mahendra, Dinamika Tata Negara Indonesia, Cet.1. Jakarta: Gema Insani Press, 1996, h. 65.

${ }^{9}$ Endang Saifuddin Anshari, Piagam Jakarta 22 Juni 1945: Sebuah Konsensus Nasional tentang Dasar Negara Republik Indonesia (1945-1959), Cet. 1., Jakarta: Gema Insani Press, 1997, h. 231-232.

${ }^{10}$ Hazairin, Demokrasi Pancasila, Cet.6., Jakarta: Rineka Cipta, 1990, h. 87.
}

Prinsip inilah yang menurut Tahir Azhary ${ }^{11}$ merupakan ciri khusus dari Negara Hukum Pancasila sekaligus yang membedakannya dari semua konsep negara hukum lain baik rechstaat, rule of law, dan socialist legalitiy. Itulah cerminan konsep monoteisme atau tauhid (unitas). Prinsip ini pula merupakan dasar kerohanian dan dasar moral bagi Bangsa Indonesia dalam bernegara, bermasyarakat, artinya penyelenggaraan kehidupan bernegara dan bermasyarakat wajib memperhatikan dan mengimplementasikan petunjuk-petunjuk Tuhan Yang Maha Esa.

Proses pembentukan Konstitusi di Konstituante sepanjang rentang 1957-1959 menjadi faktor pemicu mencuatnya kembali dialektika agama dan negara. Arus pemikiran yang digagas oleh faksi nasionalis Islam dengan dasar negara Islam ataupun faksi nasionalis sekuler mewarnai perdebatan-perdebatan dalam sidang Konstituante. Dalam hal ini, faksi nasionalis mengusulkan Pancasila, sedangkan faksi Islam menyodorkan Islam sebagai dasar negara. ${ }^{12}$ Tetapi, upaya ini menemui jalan buntu, dan dengan alasan Konstituante telah gagal memenuhi tugasnya, Soekarno mengeluarkan Dekrit Presiden 1959. Walaupun demikian, Dekrit Presiden nampaknya mengakomodasi dua arus pemikiran yang berkembang dalam Konstituante, yaitu dengan mengakomodasi pandangan faksi Islam dengan mencantumkan dalam salah satu konsiderannya bahwa Piagam Jakarta 22 Juni 1945 menjiwai UUD 1945, dan merupakan suatu rangkaian kesatuan dengan konstitusi tersebut. ${ }^{13}$ Kata menjiwai pada satu sisi berarti tidak boleh dibuat peraturan-perundangundangan yang bertentangan dengan syariat Islam bagi pemeluk-pemeluknya. Sedangkan pada sisi lain, berarti para pemeluk Islam

\footnotetext{
${ }^{11}$ Tahir Azhary, Negara Hukum Suatu Studi tentang Prinsip-prinsipnya Dilihat dari Segi Hukum Islam, Implementasinya pada Periode Negara Madinah dan Masa Kini, Cet.1., Bogor: Kencana, 2003, h.98.

${ }^{12}$ Adnan Buyung Nasution, The Aspiration for Constitutional Government in Indonesia: A Socio-Legal Study of the Indonesian Konstituante 1956-1959, Jakarta: Pustaka Sinar Harapan, 1992, h. 51.

${ }^{13} \mathrm{M}$. Amin Suma, Himpunan Undang-Undang Perdata Islam dan Peraturan Pelaksanaanya laiinya di Negara Hukum Indonesia, Jakarta: PT. RajaGrafindo Persada,
} 2004, h. 44. 
diwajibkan menjalankan syariat Islam. Hal ini tentu saja memperjelas posisi hukum Islam dalam UUD 1945, sehingga dapat dikatakan kedudukan hukum Islam dalam UUD 1945 sesudah Dekrit Presiden lebih kuat daripada dalam UUD 1945 yang disahkan oleh PPKI. Karena, penerimaan hukum islam telah menjadi sumber otoritatif dalam hukum tata negara Indonesia, dan bukan lagi sekedar sumber persuasif. ${ }^{14}$

Pada praktiknya, setidak-tidaknya kondisi tersebut dapat dilihat pada masa orde baru. Selain hukum Adat ataupun hukum Barat, hukum Islam telah menjadi salah satu sumber hukum nasional, (meski pada masa orde lama pun, justifikasi terhadap hukum Islam telah ada, sebagai contoh dengan lahirnya UU No.5 tahun 1960 yang menyandarkan kesahan hukum agraria pada hukum agama). ${ }^{15}$ Upaya ini diawali dengan lahirnya UU No.14 tahun 1970 tentang Kekuasaan Kehakiman, yang mengakui Peradilan Agama sebagai salah satu badan peradilan yang berinduk pada Mahkamah Agung. Dengan undang-undang ini - menurut Hazairin - hukum Islam telah berlaku secara langsung sebagai hukum yang berdiri sendiri. Hal ini kemudian disusul dengan berlakukannya UU No.1 tahun 1974 yang mengatur sahnya perkawinan berdasarkan hukum agama. Bagi umat Islam hukum agama adalah hukum Islam. Berdasarkan undangundang ini, perkawinan penduduk hanya sah bila dilakukan menurut keyakinan agamanya, dan setelah itu dicatatkan pada negara. Warga beragama Islam, pencatatannya di Kantor Urusan Agama, sedangkan non muslim di Kantor Catatan Sipil.

Suatu kemajuan eksistensial hukum Islam yang dapat dicatat dalam kerangka ius constitutum adalah dengan ditetapkannya UU No.7 tahun 1989 tentang Peradilan Agama (kini UU No.3 tahun 2006) dan Inpres No.1 tahun 1991 tentang Kompilasi Hukum Islam. Dengan kedua

\footnotetext{
${ }^{14}$ Ismail Sunny, Tradisi dan Inovasi Keislaman di Indonesia dalam Bingkai Hukum Islam: dalam Hukum Islam dalam Hukum Islam dalam Tatanan Masyarakat Indonesia, Cik Hasan Bisri (ed), Jakarta: Logos Publishing, 1988, h. 96.

${ }^{15}$ Lihat Pasal 5 UU No. 5 tahun 1960 tentang Peraturan Dasar Pokok-pokok Agraria.
}

peraturan tersebut, hukum Islam bukan saja diakui keberadaannya, akan tetapi secara definitif telah menjadi bagian hukum nasional, dan pilar peradilan negara, baik secara materil maupun formil. Artinya, hukum Islam menjadi bagian penting dalam restrukturisasi dan reformasi hukum nasional. Dalam bidang hukum materil, pengadilan agama diberi kewenangan untuk mengadili perkara perkawinan, kewarisan, wasiat, hibah yang dilakukan berdasarkan hukum Islam, serta wakaf dan shadaqah (bahkan kewenangan tersebut telah diperluas, yakni juga menangani persoalan hukum terkait dengan sengketa ekonomi syariah termasuk perbankan. ${ }^{16}$ Dengan demikian, secara implisit hukum Islam diterima dan diakomodasi dalam hukum negara. Selain itu secara normatif, ketentuan-ketentuan hukum Islam tidak saja mewarnai undang-undang sebagaimana yang telah disebutkan diatas, tetapi juga turut masuk dalam peraturan pemerintah, antara lain PP No.9 tahun 1975 tentang Petunjuk Pelaksanaan UU Perkawinan dan PP No.28 tahun 1977 tentang Perwakafan Tanah Milik. ${ }^{17}$

Dengan demikian dapat dikatakan, politik hukum Orde baru terhadap hukum Islam secara praktis-empiris tidak saja mengukuhkan sejarah perkembangan hukum Islam sebagai hukum positif ke dalam model pelembagaan yuridis, akan tetapi telah menempatkannya pada posisi yang penting, meski masih dalam batas-batas tertentu. ${ }^{18}$ Pada sisi lain, pada era ini, dengan ditetapkan UU No.8 tahun 1985 tentang UU Keormasan, maka partai politk dan ormas di Indonesia sejak tahun 1985 diwajibkan mencantumkan asas tunggal, yaitu Pancasila. Hal ini menimbulkan hubungan antara negara dan Islam kembali bergejolak. Alasan penetapan tersebut lebih dikarenakan kekuatan-kekuatan politik yang berdasarkan Islam dipandang sebagai pesaing kekuasaan yang potensial yang dapat mengancam, menganggu,

${ }^{16} \mathrm{Hal}$ ini didasarkan pada perubahan Pasal 49 jo. Pasal 55 ayat (2) dan (3) UU No.3 tahun 2006 tentang Perubahan Undang-Undang Nomor 7 tahun 1989 tentang Peradilan Agama.

${ }^{17}$ Marzuki Wahid dan Rumadi, Figh Mazhab Negara: Kritik Atas Politik Hukum Islam di Indonesia, Cet. 1., Edisi Revisi, Yogyakarta: Lkis, 2001, h. 87.

${ }^{18}$ Ibid., h. 88. 
dan bahkan merobohkan landasan negara yang nasionalis. Karena alasan-alasan tersebut, rezim penguasa selalu berupaya melemahkan dan menjinakan kekuatan-kekuatan politik Islam saat itu karena dicurigai menentang ideologi negara, Pancasila. Bahkan, politik Islam sering dicurigai sebagai anti ideologi negara Pancasila. Kondisi ini menandakan, pola yang dikembangkan Orde Baru sendiri yang tidak mentolelir perbedaan. ${ }^{19}$ Inilah bukti bahwa perjalanan sejarah Orde Baru yang berlangsung selama 32 tahun, terdapat kesenjangan antara das sollen dan das sein yang cenderung bersifat legal-formal dari pada sisi substantif. Realitas empirik inilah yang kemudian memperjelas bahwa hubungan agama dan negara pada masa ini bersifat akomodatif di satu sisi, dan antagonistik di sisi lain. Artinya, agama dan negara satu sama lain saling mengisi bahkan ada kecenderungan memiliki kesamaan untuk mengurangi konflik, namun pada saat yang sama ada ketegangan antara Islam sebagai sebuah agama dengan negara. ${ }^{20}$

Pada Perubahan UUD 1945 (1999-2002) muncul kembali dialektika agama dan negara. Selama proses perubahan dari tahun 1999 sampai tahun 2002, isu-isu peka dan pernah tabu untuk dibicarakan, seperti isu apakah Pembukaan UUD 1945 perlu diubah, isu untuk memasukkan kembali "tujuh kata: dengan kewajiban menjalankan syariah Islam bagi pemeluk-pemeluknya" seperti dirumuskan pada rancangan Piagam Jakarta akan dimasukkan kembali ke dalam Pasal 29 UUD, untuk pertama kalinya dalam sejarah Indonesia dibicarakan secara terus-terang dalam forum lembaga resmi pada masa itu. Sebagai contoh Fraksi PBB dan PPP mengusulkan redaksi Pasal 29 UUD 1945 sebagai berikut: (1) negara berdasarkan Ketuhanan Yang maha Esa dengan berkewajiban menjalankan syari' at Islam bagi pemeluk-pemeluknya; (2) negara menjamin kemerdekaan tiap-tiap penduduk untuk memeluk agamanya masing-masing dan untuk beribadat menurut agamanya

${ }^{19}$ Lihat Bachtiar Effendi, Teologi Baru Politik Islam: Pertautan Agama, Negara dan Demokrasi, Yogyakarta: Galang Press, 2001, h. 4.

${ }^{20}$ Tentang hal ini dapat dilihat M. Imam Aziz, Agama, Demokrasi dan Keadilan, Jakarta: Gramedia Pustaka Utama, 1993, h. 105. itu. Pada ayat (2) ini kata "kepercayaan" dihilangkan karena di masa lalu, kata-kata itu disalahtafsirkan dan disalahgunakan untuk menumbuhsuburkan aliran kepercayaan, dan dianggap bertentangan dengan maksud rumusan semula. (3) Negara melindungi penduduk dari penyebaran paham-paham yang bertentangan dengan Ketuhanan Yang Maha Esa. Kedua fraksi tersebut menegaskan bahwa dengan usulan seperti ini, maka larangan terhadap komunisme dalam TAP Nomor XXV/MPRS/1966 yang semula di dalam UUD bersifatimplisit, menjadieksplisit. Dengan demikian di masa depan tidak ada lagi kontroversial TAP MPRS itu dengan UUD.

Dalam sidang PAH I, pembahasan pasal 29 berjalan sangat seru dan cukup alot, sehingga melahirkan empat alternatif. Rancangan rumusan alternatif pertama adalah tetap seperti rumusan lama. Kedua, negara berdasar atas Ketuhanan Yang Maha Esa dengan kewajiban menjalankan syari'at Islam bagi pemeluk-pemeluknya. Ketiga, negara berdasar atas Ketuhanan Yang Maha Esa dengan kewajiban melaksanakan ajaran agama bagi masing-masing pemeluknya. Keempat, negara berdasarkan atas Ketuhanan Yang maha Esa, kemanusiaan yang adil dan beradab, persatuan Indonesia, kerakyatan yang dipimpin oleh hikmah kebijaksanaan dalam permusyawaratan/ perwakilan, dan keadilan sosial bagi seluruh rakyat Indonesia. Terhadap alternatif ini Fraksi PPP dan Fraksi PBB memilih alternatif kedua. Fraksi Reformasi dan Fraksi PKB memilih alternatif ketiga, sisanya termasuk Fraksi PDIP memilih alternatif pertama.

Di luar saluran institusi-institusi politik, isu Piagam Jakarta dalam usulan perubahan Pasal 29 UUD 1945, juga terjadi pro kontra antar beberapa kelompok masyarakat. Alhasil, akhir perdebatan yang berlangsung selama 1999-2002, mayoritas fraksi dan anggota MPR menyepakati rumusan Pasal 29 UUD 1945 tidak ada perubahan. Pada saat yang sama, pada Perubahan Keempat disepakati adanya penegasan bahwa UUD 1945 adalah UUD yang disahkan pada 18 Agustus 1945 dan diberlakukan kembali dengan Dekrit Presiden 
5 Juli 1959. ${ }^{21}$ Adanya penegasan demikian, bahwa pemberlakuan kembali UUD 1945 dengan Dekrit Presiden 5 Juli 1959, adalah hendak menyatakan bahwa piagam tersebut menjadi bagian yang tak terpisahkan dari UUD ini.

\section{Aktualitas Hukum Islam dalam Sistem Hukum Nasional}

Berlakunya hukum Islam di Indonesia telah mendapat tempat konstitusional yang berdasar pada tiga alasan, yaitu: Pertama, alasan filosofis, ajaran Islam rnerupakan pandangan hidup, cita moral dan cita hukum mayoritas rakyat Indonesia yang beragama Islam dan mempunyai peran penting bagi terciptanya norma fundamental negara Pancasila; Kedua, alasan sosiologis, yaitu perkembangan sejarah hukum di Indonesia menunjukan bahwa cita hukum dan keberadaan hukum bersendikan ajaran Islam memiliki tingkat aktualitas yang berkesinambungan; dan Ketiga, alasan konstitusional sebagaimana tercantum dalam konsideran Dekrit Presiden 5 Juli 1959 yang dikukuhkan kembali pada Perubahan Keempat pada 2002, yang menegaskan Piagam Jakarta (yang didalamnya bermakna syari' at Islam) adalah menjiwai dan menjadi bagian yang tidak terpisahkan dari UUD ini. Setelah Indonesia merdeka, pembentukan hukum nasional Indonesia memang tidak hanya bersumber dari hukum Islam, tetapi memperoleh pengaruh dari hukum Eropa warisan Belanda serta hukum Adat. ${ }^{22}$ Inilah sistem hukum nasional kita, sistem hukum yang majemuk. Terdapat perkembangan yang semakin menarik setelah 60 tahun lebih Indonesia merdeka, yaitu saling pengaruh ketiga kelompok hukum ini mewarnai perdebatan politik hukum nasional Indonesia bahkan nampak terjadi gesekangesekan sosial dalam pembangunan hukum Indonesia. Walaupun harus diakui, hingga saat ini pengaruh hukum Eropa bahkan hukum Anglo-Amerika mendapat kedudukan yang semakin kuat terutama dalam bidang hukum bisnis dan perdagangan, dan disusul oleh

\footnotetext{
${ }^{21}$ Lihat Perubahan Keempat UUD 1945.

${ }^{22}$ Daniel S. Lev, Hukum dan Politik di Indonesia, Kesinambungan dan Perubahan, Jakarta: LP3ES, 1990.
}

hukum Islam terutama dalam bidang bisnis keuangan dan perbankan. Sementara hukum Adat jauh tertinggal dan hanya bertahan untuk sebahagiannya dalam hukum pertanahan.

Dalam konteks Islam sebagai agama yang dianut mayoritas bangsa, sesuai dengan teori kepentingan (public interest theory) dalam hukum tata negara, salah satu tugas dan kewajiban negara adalah mengakomodasi dan memperhatikan keingingan dan kepentingan para warganya dalam hal ini antara lain keingingan dan kepentingan umat Islam di Indonesia supaya hukum Islam berlaku secara sempurna di negara Republik Indonesia. ${ }^{23}$ Karenanya, ditengah hiruk pikuknya dinamika keterbukaan di era reformasi, berbagai kelompok Islam kembali menyuarakan hukum Islam sebagai sebuah agenda yang harus mendapat perhatian. Tampaknya, era reformasi telah membuka peluang tersebut. Dalam proses pembentukan hukum nasional, kedudukan hukum Islam dalam sistem hukum di Indonesia semakin memperoleh pengakuan dan kedudukan yang penting. Pada saat yang sama demokratisasi dalam pembentukan hukum, peran para tokoh Islam dan partai-partai politik Islam dan partai politik berbasis Islam sangat mempengaruhi perkembangan dan pembentukan hukum nasional yang di pengaruhi oleh hukum Islam. Pengakuan berlakunya hukum Islam dalam bentuk peraturan dan perundang-undangan berpengaruh terhadap pranata-pranata sosial, budaya, politik dan hukum yang ada dalam masyarakat. Pada kenyataannya sebagian besar hukum Islam yang berlaku, tidak lagi terbatas pada bidang hukum keluarga seperti hukum perkawinan, hukum kewarisan, hukum perwakafan, tetapi telah meluas di bidang mu'amalah, khususnya hukum bisnis dan perdagangan. Bahkan secara formal untuk hukum pidana telah diterapkan di NAD. Contoh undang-undang yang secara formil maupun materi memiliki muatan yuridis hukum Islam, antara lain UU No. 13 Tahun 2008 tentang Penyelenggaraan Ibadah Haji jo. UU No. 34 tahun 2009 tentang Penetapan

\footnotetext{
${ }^{23}$ Tahir Azhary,et.al, Beberapa Aspek Hukum Tata Negara, Hukum Pidana dan Hukum Islam, Bogor: Kecana , 2012, h. 491.
} 
Peraturan Pemerintah Pengganti UU No.2 tahun 2009 tentang Perubahan atas UU No. 13 tahun 2008 tentang Penyelenggara Ibadah Haji Menjadi Undang-undang, UU No. 23 Tahun 2011 tentang Pengelolaan Zakat, UU No. 4 Tahun 1999 tentang Penyelenggaraan Keistimewaan Propinsi Daerah Aceh, UU No. 18 tahun 2001 tentang Otonomi Khusus Bagi Provinsi Daerah Istimewa Aceh sebagai Provinsi Nanggroe Aceh Darussalam, UU No. 41 Tahun 2004 tentang Wakaf, UU No. 3 Tahun 2006 tentang Perubahan Atas UndangUndang Nomor 7 Tahun 1989 tentang Peradilan Agama, UU No. 19 Tahun 2008 tentang Surat Berharga Syariah Negara, UU No. 21 Tahun 2008 tentang Perbankan Syariah. Belum lagi prinisip-prinsip hukum Islam yang secara parsial masuk dalam bagian undang-undang lain setelah reformasi. Demikian juga berbagai peraturan daerah yang sangat dipengaruhi oleh semangat menegakkan syaria't tersebut.

Sungguhpun demikian, lahirnya aneka peraturan perundangundangan yang memuat nilai-nilai hukum Islam tidak lepas dari masalah. Upaya legislasi hukum Islam selalu menimbulkan kontroversi baik bersifat teknis yuridis maupun politis. Polemik itu muncul karena posisi hukum Islam berada di titik tengah antara paradigma hubungan antara agama dan negara dan bahkan berada di titik tengah ketegangan antara agama itu sendiri. Berkenaan dengan hal ini, mungkin kita dapat melihat contoh pemberlakuan hukum pidana di NAD, yakni penerapan hukum "jilid" atau cambuk bagi pelaku tindak pidana perjudian yang telah menimbulkan perdebatan hangat di kalangan masyarakat. Seakan-akan jenis hukuman ini adalah baru dalam khasanah ketentuan hukum pidana di Indonesia. Padahal pelaksanaan hukum pidana Islam di Indonesia telah dipraktekkan di berbagai kesultanan di Indonesia sebelum dikuasai oleh penjajah Belanda. Dalam disertasi doktornya, Rifyal Ka'bah menulis bahwa "sebelum kedatangan penjajah Belanda, hukum Islam telah merupakan hukum positif di kerajaan-kerajaan Islam yang berdiri di persada Indonesia" ${ }^{24}$ Demikian juga

\footnotetext{
${ }^{24}$ Rifyal Ka'bah, Hukum Islam di Indonesia,
}

berbagai data yang ditulis dalam disertasi doktor dari Abdul Gani Abdullah yang menulis tentang peradilan agama dalam pemerintahan Islam di kesultanan Bima 1947-1957. ${ }^{25}$ Kenyataan ini menunjukkan bahwa pelaksanaan hukum Islam bukanlah hal baru dalam khasanah hukum Indonesia. Persoalannya adalah dengan perkembangan hukum yang sedemikian rupa setelah Indonesia merdeka masalah penerapan hukum Islam ini menjadi aneh dan menimbulkan perdebatan publik yang luas.

Sebenarnya jenis-jenis tindak pidana dalam hukum pidana Islam yang secara tegas diatur dalam Al Qur'an dan As Sunnah hanya terdiri dari 9 jenis tindak pidana, yang secara garis besar terdiri dari tindak pidana " $h u d u d "$ yaitu 7 jenis tindak pidana dan tindak pidana "qishash" dan "diyat" yaitu 4 jenis tindak pidana. Adapun bagian terbesar tindak pidana dalam hukum pidana Islam diserahkan pada kewenangan pemerintah setempat atau hakim untuk menetapkannya yang dalam terminologi hukum Islam disebut " $t a ' z i r$ ", yaitu seluruh tindak pidana yang dapat ditetapkan oleh pemerintah setempat atau oleh hakim selain yang ditentukan dalam jenis tindak pidana "hudud" dan tindak pidana "qishash" .

Bagi sebagian ummat Islam berkeyakinan bahwa pelaksanaan hukum Islam termasuk dalam bidang hukum pidana ini adalah bagian dari ketaatannya pada perintah ajaran agama, danjika tidak melaksanakannya dianggap telah menentang pelaksanaan ajaran agama. Dalam kerangka pemikiran inilah perjuangan untuk pelaksanaan syari' at Islam bagi pemeluk agama Islam di Indonesia dapat dipahami, walaupun harus diakui ada sebagian ummat Islam yang berpandangan lain. Bagi kalangan ummat Islam yang mendukung pelaksanaan syari'at Islam, perdebatan lebih jauh lagi sebenarnya adalah bukan pada melaksanakan syari'ah atau tidak melaksanakan syari'ah, akan tetapi bagaimana syari'ah (hukum pidana Islam) itu dijalankan pada masa kini. Sehingga timbulah kehendak untuk melakukan rekonstruksi dan kaji kembali

\footnotetext{
Jakarta:Universitas Yarsi, 1999, h. 264

${ }^{25}$ Abdul Gani Abdullah, Peradilan Agama Dalam Pemerintahan Islam di Kesultanan Bima (1947-1957), Mataram: Yayasan Lengge, 2004.
} 
metode dan pelaksanaan syari'ah.

Sebagian kalangan ummat berprinsip bahwa persoalan hudud dan qishash tidak bisa direkonstruksi dalam arti merubah jenis pidana yang dijatuhkan kecuali dalam batasbatas yang ditentukan oleh Al Qur'an atau As Sunnah. Pada sisi lain sebagian kalangan ummat Islam berkeyakinan bahwa yang prinsip adalah prinsip-prinsip dan substansi (material delik) pidana Islam dilaksanakan, adapaun masalah bentuk hukuman pidananya di sesuaikan dengan idiologi humanisme yang sedang berkembang pada saat ini. Sebenarnya masalah ini tidak harus menjadi perdebatan diantara kalangan ummat Islam, karena nashnash Al Qur'an dan As Sunnah mengenai hudud maupun qishash adalah jelas (qath'i) sifatnya. Karena itu, tidak bisa dihilangkan, dirubah atau dihapuskan. Adapun masalah akan diterapkan atau tidak, dapat dilihat pada penerapannya dalam kasus in concrito. Artinya hudud maupun qishash hanya dapat diterapkan apabila memenuhi syarat-syarat perbuatan pidana yang sedemikian rupa kwalitasnya baik dari sisi beratnya tindak pidana yang dilakukan, dari sisi causanya, maupun pengaruhnya pada bidang sosial dan publik. Bukankah Umar ra pernah tidak menghukum pencuri dengan potong tangan karena kondisi sosial dan keadaan si pencuri yang sedemikian sulitnya. Dengan demikian, tidak melakukan perubahan atas hukum yang telah ditentukan dengan pasti oleh Allah.

Sebenarnya penerapan bentuk pemidanaan dari hukum pidana Islam memiliki efek keuntungan ganda baik dari sisi efektivitasnya dalam pencegahan kejahatan maupun dari sisi efisiensi pembiayaan negara yang dikeluarkan. Sebagai contoh, dengan penerapan pidana yang secara langsung dan dapat disaksikan oleh publik memiliki efek jera yang luar biasa dan secara psikologis memiliki efek malu dan pendidikan bagi pelaku tindak pidana dan masyarakat lainnya dan ditambah lagi tidak memerlukan biaya dan anggaran besar.

Penerapan syari' ah Islam diNAD dilaksanakan berdasarkan undang-undang otonomi khusus dengan melakukan transplantasi syar'iah ke dalam hukum positif dalam bentuk "Qanun". Kebijakan ini dikeluarkan sehubungan dengan tuntutan dan permintaan masyarakat Aceh atas pelaksanaan hukum yang khusus dalam wilayah NAD yang memiliki kekhasan sosial dan sejarahnya. Dari cantoh kasus NAD ini, ternyata bahwa politik hukum nasional Indonesia menjadi sangat fleksibel dalam menerapkan pluralitas hukum yang berlaku dalam wilayah NKRI. Artinya politik unifikasi hukum terutama dalam bidang hukum pidana (hukum publik) yang terus diperjuangkan sejak lepas dari tangan penjajah Belanda mengalami perubahan. Paradigma politik unifikasi hukum yang dilakukan selama ini tidak sesuai dengan kondisi masyarakat Indonesia yang sangat plural dan majemuk yang memiliki ragam hukum yang berbeda-beda, apalagi sudah masuk dalam bidang hukum yang sensitif yang terkait dengan ajaran agama. Karena itu unifikasi hukum tidak dapat dipaksakan. Di luar masalah penegakan yang belum maksimal pada saat sekarang ini, kebijakan penerapan syari'at Islam di NAD adalah langkah tepat untuk menghormati kehendak masyarakat yang menginginkannya.

Tidak hanya di pusat, tuntutan yang mengusung hukum Islam juga telah sampai pada upaya positivikasi syari'at kedalam perundang-undangan di daerah lainnya melalui Peraturan Daerah (Perda) dan Peraturan Gubernur atau Peraturan Bupati/Walikota. Hal ini telah mengundang kontroversi, sekalipun Perda tersebut lahir dalam konteks demokrasi lokal. Kontroversi ini sesungguhnya bukanlah sesuatu yang mengejutkan. Jauh sebelum itu, Abul A'la Al-Maududi ${ }^{26}$, pemikir muslim Pakistan sudah memprediksi bahwa ketika diskursus tentang penerapan syari'ah ini muncul maka sesungguhnya pertanyaan dan protes bukan hanya muncul dari kalangan non muslim tapi juga dari elit muslim yang terdidik. Tidak ada catatan yang rinci untuk memastikan kapan Perda-perda yang bernuansa syari'ah itu muncul di Indonesia. Namun

\footnotetext{
${ }^{26}$ Abul A'la Al-Maududi, Islamic Lawand Constitution,
} Karachi: Jama'at al-Islami Publication, 1995, h.13 
melihat perkembangannya Perda syari'ah mulai tumbuh ketika perdebatan panjang tentang perubahan UUD 1945 (1999-2002) yang juga terjadi perdebatan tentang berlakunya hukum Islam di Indonesia. Sejauh ini di beberapa daerah memang telah terbit Perda bernuansa syari'ah misalnya di Bulukumba, Sulawesi Selatan terdapat Perda No. 03/2002 tentang Larangan, Penerbitan dan Penjualan Minuman Keras, Perda No. 02/2003 tentang Pengelolaan Zakat, Infak, dan Sedekah. Masih dari Sulawesi Selatan, yakni Maros terdapat Perda No. 15,16, 17 tahun 2005 tentang Buta Aksara Al Qur'an, dan Pengelolaan Zakat. Di Lombok Timur, Nusa Tenggara Barat ada Perda No.09 tentang Zakat Profesi. Di Pamengkasan, Madura terdapat Perda No. 18/2001 tentang Larangan Peredaran Minuman Beralkohol.

Keberadaan Perda-perda Syari'ah tersebut diatas hakekatnya menunjukkan adanya dukungan terhadap hukum atau syari'ah Islam untuk berlaku di daerah tertentu, dan melihat perkembangannya, tidak mustahil jumlah Perda Syari'ah akan bertambang di masa mendatang. Kondisi tersebut dapat dipahami, karena nilai-nilai Islam seperti halnya nilainilai adat dan Barat telah ratusan tahun hidup dalam pergaulan masyarakat Indonesia (living law), sehingga nilai-nilai itu dapat saja diserap ke dalam peraturan perundang-undangan sepanjang untuk kemaslahatan. Kehadiran perda bermuatan syari'ah merupakan manifestasi dari pluralisme sistem hukum di Indonesia yang terdiri dari hukum Adat, hukum Islam, dan hukum Barat. Dengan demikian, lahirnya perda-perda yang bersifat khusus di daerahdaerah termasuk perda yang bersumber dari nilai-lai syari'ah, seharusnya dipahami sebagai bentuk penghormatan terhadap keragaman daerah di Indonesia sebagai sebuah negara yang plural.

Hal terpenting dan tak dapat diabaikan adalah isi dari berbagai perda-perda tersebut tidak menimbulkan diskriminasi bagi penganut agama yang lain. Artinya, sepanjang Perdaperda dalam rangka menjalankan syari' at Islam itu tidak diberlakukan kepada penganut agama-agama lain, kecuali Perda-perda tersebut mengenai ketertiban umum yang bersumber dari ajaran Islam. Satu hal yang patut digarisbawahi adalah perlu ada pemahaman yang benar tentang penyusunan perda yang bersumber dari syari'ah ini, termasuk tehnik penyusunan Perda, sehingga tidak menimbulkan salah pengertian dan dianggap keluar dari prinsip Negara Kesatuan Republik Indonesia. Sebagai contoh, Perda-perda tersebut tidak boleh bertentangan dengan ketentuan hak-hak dan kewajiban asasi manusia seperti yang tertera di dalam UUD 1945, dengan memperhatikan kekompakan hirarkis dengan perundangundangan yang ada di atasnya.

\section{Pelembagaan Hukum Islam dan Pemba- ngunan Hukum Nasional}

Sebagai negara demokrasi - walaupun masih pada tahap demokrasi yang belum mapan - proses pembentukan hukum di Indonesia sangat dipengaruhi oleh kekuatan-kekuatan politik yang ada dan berbeda ideologi dan kepentingan politiknya. Hukum yang lahir dari negara demokratis sangat dipengaruhi oleh kekuatan dan pendapat rakyat melalui prosedur demokrasi, dan hal ini berbeda dengan negara otoriter yang sangat dipengaruhi oleh pihak penguasa. Walaupun harus diakui, pada kenyataannya pembentukan hukum sangat didomisasi oleh elit-elit politik yang memiliki otoritas yang dianggap representasi rakyat dan di lain pihak keterlibatan rakyat secara langsung masih minim. Corak pembentukan hukum juga sangat dipengaruhi oleh tingkat perkembangan masyarakat, yaitu kenyataan sosial kemasyarakatan yang ada. Karena itu pendekatan dalam pembentukan hukum disesuaikan dengan kondisi pragmatik masyarakat yang ada, baik karena tingkat ekonomi, budaya, ilmu pengetahuan dan teknologi serta kepercayaan agama masyarakat Indonesia. Akan berbeda halnya dengan negara yang memiliki corak masyarakat yang menganut nilai-nilai yang bebas, pembentukan hukum itu hanya semata-mata ditujukan pada tujuan pembentukan hukum saja yang hanya ditujukan kepada manusia (prinsip humanisme). Pada negara yang mayoritas masyarakatnya menganut 
standar nilai-nilai tertentu, maka pembentukan hukumnya patut memperhatikan nilai-nilai dan keyakinan yang hidup di tengah-tengah masyarakat itu, yaitu menghormati nilai-nilai dan kepercayaan yang dianut oleh masyarakat tersebut.

Sejalan dengan hal diatas, pembentukan hukum Indonesia diarahkan pada terwujudnya sistem hukum nasional yang mengabdi pada kepentingan nasional. Penyusunan awal materi hukum secara menyeluruh haruslah bersumber dari nilai-nilai Pancasila. Hanya saja harus diakui, untuk mewujudkan satu hukum nasional bagi bangsa Indonesia yang terdiri atas berbagai suku bangsa dengan budaya dan agama yang berbeda, ditambah dengan keanekaragaman hukum yang ditinggalkan oleh pemerintah kolonial, bukan pekerjaan mudah. Idealnya, pembangunan hukum nasional yang berlaku bagi semua warga negara tanpa memandang agama yang dipeluknya, harus dilakukan dengan hati-hati, karena di antara agama yang dipeluk oleh warga negara Indonesia, ada agama yang tidak dapat dicerai-pisahkan dari hukum. Agama Islam adalah agama yang mengandung hukum yang mengatur hubungan manusia dengan manusia lain, alam semesta, disamping hubungan dengan Tuhan yang bersifat pribadi. Dalam hal ini, Islam adalah agama hukum dalam arti kata yang sesungguhnya. Oleh karena itu, dalam pembangunan hukum nasional di negara yang mayoritas penduduknya beragama Islam seperti di Indonesia, unsur-unsur hukum agama itu harus benar-benar diperhatikan. Hal ini memerlukan wawasan dan kebijakan yang jelas. $^{27}$

Oleh karena hukum nasional kita harus mengayomi dan memayungi seluruh bangsa dan negara dalam segala aspek kehidupannya, maka dalam merencanakan pembangunan hukum nasional, harus mengedepankan wawasan nasional, yaitu: wawasan kebangsaan, wawasan nusantara dan wawasan bhineka tunggal ika. Dipandang dari wawasan kebangsaan sistem hukum nasional harus berorientasi pada aspirasi serta kepentingan bangsa Indonesia

${ }^{27}$ Muhammad Daud Ali, op.cit., h. 268. serta mencerminkan cita-cita hukum dan tujuan kehidupan berbangsa dan bernegara Indonesia. Dilihat dari sudut pandang ini, hukum nasional Indonesia yang akan datang haruslah merupakan hukum modern, sesuai dengan perkembangan serta kebutuhan zaman, namun tetap berpijak pada kepribadian bangsa. Pengertian kepentingan bangsa adalah kepentingan seluruh bangsa Indonesia yang menyatu dalam kehidupan berbangsa dan bernegara. Wawasan kebangsaan ini, bukanlah wawasan kebangsaan yang tertutup, tetapi wawasan yang terbuka memperhatikan kepentingan generasi yang akan datang dan mampu menyerap nilai-nilai hukum modern. ${ }^{28}$

Karena yang dianut dalam pembangunan hukum nasional juga wawasan nusantara yang menginginkan adanya satu hukum nasional, maka usaha unifikasi di bidang hukum harus sejauh mungkin dilaksanakan. Ini berarti seluruh golongan masyarakat akan diatur oleh satu sistem hukum yaitu sistem hukum nasional. Untuk itu perlu diciptakan iklim kehidupan di segala bidang yang dapat mendorong tumbuhnya kesadaran hidup dibawah satu hukum bagi semua golongan masyarakat. Ini berarti pula bahwa seluruh golongan masyarakat akan diatur oleh satu sistem hukum yang sama yaitu, 'sistem hukum nasional'. Walaupun berdasarkan dua wawasan itu, unifikasi hukum merupakan tujuan pembangunan hukum nasional, akan tetapi demi keadilan, hukum nasional yang akan diwujudkan itu harus juga memperhatikan perbedaan sosial, budaya dan kebutuhan hukum yang dimiliki oleh kelompok-kelompok tertentu dalam masyarakat. Oleh karena itu, di samping kedua wawasan tersebut, pembangunan hukum nasional harus memperhatikan kebutuhan-kebutuhan hukum khusus golongan rakyat tertentu, sehingga kelompok masyarakat tersebut merasa mendapat perlakuan yang adil. Dengan demikian, selain wawasan kebangsaan dan wawasan nusantara sebagaimana dikemukakan diatas, perlu wawasan bhineka tunggal ika. Dengan ketiga wawasan tersebut, unifikasi

\footnotetext{
${ }^{28}$ Ibid.,h. 270.
} 
hukum yang diinginkan harus menampung aspirasi, nilai-nilai dan kebutuhan hubungan masyarakat ke dalam sistem hukum nasional, yang dengan sendirinya harus sesuai atau setidaktidaknya tidak bertentangan dengan aspirasi dan kehidupan berbangsa dan bernengara. Dengan mempergunakan ketiga wawasan itu secara serentak dan terpadu, berbagai asas dan kaidah hukum Islam, juga hukum Adat dan hukum Barat bahkan pengaruh hukum lain termasuk Konvensi Internasional terintegrasi menjadi hukum nasional. ${ }^{29}$

Hukum Islam yang secara substansi terdiri atas dua bagian besar yaitu: (1) hukum yang terkait bidang ibadah dan (2) hukum yang terkait bidang mu'amalah. Pengaturan bidang ibadah bersifat rinci, sedangkan pengaturan mengenai mu'amalah atau mengenai segala aspek kehidupan masyarakat tidak bersifat rinci, yang ditemukan dalam bidang terakhir ini hanya prinsip-prinsipnya saja. Pada dasarnya, pembangunan dan aplikasi prinsip-prinsip bidang mu'amalah itu diserahkan sepenuhnya kepada para penyelenggara negara dan pemerintahan yakni para ulil amri. Karena hukum Islam memegang peranan penting dalam membentuk dan membina ketertiban sosial ummat Islam dan mempengaruhi segala segi kehidupannya, maka jalan terbaik yang dapat ditempuh ialah mentransformasi norma-norma hukum Islam ke dalam hukum nasional sehingga dapat berjalan secara universal. Dalam hal ini, cukup banyak asas yang bersifat universal terkandung dalam hukum Islam yang dapat dipergunakan dalam menyusun hukum nasional. ${ }^{30}$

Dalam konteks kenegaraan, pelaksanaan dan pelembagaan hukum Islam tidak dapat dilepaskan dari proses legislasi. Meski dalam teks ajaran hukum Islam, tidak ada keharusan memberlakukan hukum Islam melalui legislasi. Namun menurut kaidah ushul fiqh, "sesuatu yang mubah bisa menjadi wajib, jika manfaat yang diberikan oleh sesuatu itu lebih besar bagi terlaksana s esuatu yang diperintahkan". Atas dasar itu, jika efektivitas hukum Islam memerlukan campur tangan pemerintah,

\footnotetext{
${ }^{29}$ Ibid., h. 272.

${ }^{30} \mathrm{Ibid}$.
}

maka legislasi merupakan kebutuhan yang urgen. ${ }^{31}$ Yang jelas transformasi hukum Islam ke dalam bentuk legislasi berarti menjadikan hukum Islam sebagai hukum negara. Artinya, hukum Islam diangkat dan dikuatkan menjadi hukum negara.

Kesempatan dan sarana penting bagi transformasi hukum Islam adalah memasukkan nilai-nilai hukum Islam ke dalam peraturan perundang-undang dan tidak berarti harus secara langsung menjadikan undang-undang tersendiri. Model ini lebih memperkecil perdebatan normatif dibanding dengan menjadikan hukum Islam dalam sebuah undang-undang tertentu, sehingga dalam waktu bersamaan akan mempunyai jangkauan yang lebih luas, karena akan mampu meliputi banyak aspek atau jenis hukum atau undangundang. Model seperti ini dilakukan dengan memasukkan norma dan prinsip hukum Islam ke dalam hukum nasional secara akademik, argumentatif, sosiologis, kultural dan asas kemanfaatan demi tercapainya cita-cita dan kemaslahatan bangsa. Pendekatan seperti ini juga dapat dilakukan ketika hakim atau penegak hukum berbicara mengenai kebiasaan dan doktrin sebagai sumber hukum. ${ }^{32}$

Untuk mengembangkan proses transformasi hukum Islam ke dalam hukum nasional, diperlukan partisipasi semua pihak dan lembaga terkait, seperti halnya hubungan hukum Islam dengan badan kekuasaan negara yang mengacu kepada kebijakan politik hukum yang ditetapkan. Politik hukum tersebut merupakan produk interaksi kalangan elite politik yang berbasis kepada berbagai kelompok sosial budaya. Ketika elite politik Islam memiliki daya tawar yang kuat dalam interaksi politik itu, maka peluang bagi pengembangan hukum Islam untuk ditransformasikan semakin besar. Langkah penting lain adalah, setidaknya transformasi hukum Islam tersebut berjalan dengan mekanisme demokrasi. Bila mekanisme demokrasi dijalankan dalam membentuk

\footnotetext{
${ }^{31}$ Mustofa dan Abdul Wahid, Hukum Islam Kontemporer, Jakarta: Sinar Grafika, 2009, h. 126.

${ }^{32}$ Qodri Azizy, Eksistensi Hukum Nasional: Kompetisi antara Hukum Islam dan Hukum Umum, Yogyakarta: Gama Media Offset, 2004, h. 232.
} 
undang-undang, dan proses transformasi berjalan, maka peran dan keterlibatan penegak hukum menemui jalan mulus, tak canggung dan phobi dengan hukum Islam, dan tidak ada dikotomi hukum Islam dan hukum nasional, sehingga hukum Islam dengan sendirinya merupakan hukum nasional.

Dengan demikian, jelas kiranya langkah yang akan diambil dalam mewujudkan hukum nasional, dan jelas pula kedudukan hukum Islam di dalamnya. Artinya, dalam pembangunan hukum nasional, keberadaan hukum Islam menjadi sumber bahan baku penyusunan hukum nasional, disamping hukum-hukum yang lain. Ini berarti bahwa sesuai dengan kedudukannya sebagai salah satu sumber bahan baku dalam pembentukan hukum nasional, hukum Islam sesuai dengan kemauan dan kemampuan hukum Islam itu harus ditunjang oleh setiap orang Islam, baik pribadi maupun kelompok, yang mempunyai komitmen terhadap Islam dan ingin hukum Islam berlaku bagi ummat Islam dalam Negara Republik Indonesia.

\section{Kesimpulan}

Uraian diatas menunjukan dengan jelas bahwa antara agama (khususnya Islam), Pancasila dan Negara dalam kasus Indonesia tidak dapat dipertentangkan antar satu dengan yang lainnya. Negara Indonesia telah dibangun dengan cita ideal yang menempatkan agama

\section{DAFTAR PUSTAKA}

Abdul Gani Abdullah. Peradilan Agama Dalam Pemerintahan Islam di Kesultanan Bima (1947-1957). Mataram: Yayasan Lengge, 2004.

Abul A'la Al-Maududi. Islamic Law and Constitution. Karachi: Jama'at al-Islami Publication, 1995.

Adnan Buyung Nasution. The Aspiration for Constitutional Government in Indonesia: A Socio-Legal Study of the Indonesian Konstituante 1956-1959. Jakarta: Pustaka Sinar Harapan, 1992. dalam posisi yang istimewa, dan sangat mempengaruhi kebijakan negara, bahkan agama masuk dalam ranah negara. Hal itu sangat berbeda dengan negara yang menganut prinsip sekularisme. Bangunan negara yang diidealkan itu adalah bangunan negara yang didasarkan pada Pancasila yang sila pertamanya adalah Ketuhanan Yang Maha Esa. Sebagaimana terekam dalam perdebatan dan perumusan Konstitusi maupun praktek kehidupan bernegara, Islam menempati posisi penting dalam pembentukan negara. Rumusan Pancasila adalah kompromi sangat penting yang mengakomodasi seluruh kepentingan bangsa Indonesia yang plural termasuk kepentingan ummat Islam yang semula hendak membentuk negara berdasarkan Islam. Seluruh nilai-nilai Pancasila tidak ada yang bertentangan dengan Islam. Hukum Islam baik dalam tataran konsep, dasar filosofis maupun landasan konstitusional memiliki dasar legitimasi maupun konstitusional untuk diberlakukan dalam tata hukum Indonesia. Lebih dari itu, hukum Islam sangat berpengaruh terhadap tata hukum nasional menjadi sumber utama dan terpenting dalam pembentukan hukum nasional, disamping bersumber dari hukum Barat, hukum Adat, perjanjian Internasional maupun pengaruh sistem hukum lain yang berkembang di dunia.

Anders Uhli. Oposisi Beserak, Arus Deras Demokratisasi Gelombang Ketiga di Indonesia. Cet. 2. Bandung: Mizan, 1998.

Bachtiar Efendi. Teologi Baru Politik Islam: Pertautan Agama, Negara dan Demokrasi. Yogyakarta: Galang Press, 2001.

Cik Hasan Bisri. Hukum Islam dalam Hukum Islam dalam Tatanan Masyarakat Indonesia. Jakarta: Logos Publishing, 1988 (ed).

Cik Hasan Bisri. Kompilasi Hukum Islam dan Peradilan Agama dalam Sistem Hukum Nasional. Jakarta: Logos, 1999. 
Daniel S. Lev. Hukum dan Politik di Indonesia, Kesinambungan dan Perubahan. Jakarta: LP3ES, 1990.

Endang Saifuddin Anshari. Piagam Jakarta 22 Juni 1945: Sebuah Konsensus Nasional tentang Dasar Negara Republik Indonesia (1945-1959). Cet. 1. Jakarta: Gema Insani Press, 1997.

Hamka. Sejarah Umat Islam. Bukit Tinggi: N.V. Nusantara, 1961.

Hazairin. Demokrasi Pancasila. Cet.6. Jakarta: Rineka Cipta, 1990.

M. Amin Suma. Himpunan Undang-Undang Perdata Islam dan Peraturan Pelaksanaanya laiinya di Negara Hukum Indonesia. Jakarta: PT. RajaGrafindo Persada, 2004.

M. Imam Aziz. Agama. Demokrasi dan Keadilan. Jakarta: Gramedia Pustaka Utama, 1993.

Marzuki Wahid dan Rumadi. Figh Mazhab Negara: Kritik Atas Politik Hukum Islam di Indonesia. Cet. 1. Edisi Revisi. Yogyakarta: Lkis, 2001.

Masykuri Abdillah. Demokrasi di Persimpangan: Respon Intelektual Muslim Indonesia Terhadap Konsep Dmeokrasi. Yogyakarta: Tiara Wacana, 1999.
Muhammad Yamin. Naskah Persiapan UndangUndang Dasar 1945. Naskah I. Jakarta: Yayasan Prapanca, 1959.

Muhammad Daud Ali. Pengantar Ilmu Hukum dan Tata Hukum Islam di Indonesia. Jakarta: Rajawali Press, 2009.

Mustofadan AbdulWahid. Hukum Islam Kontermporer. Jakarta: Sinar Grafika, 2009.

Roeslan Abdul Gani. Sejarah Perkembangan Islam di Indonesia. Jakarta: Antar Kota, 1983.

Tahir Azhary. Negara Hukum Suatu Studi tentang Prinsip-prinsipnya Dilihat dari Segi Hukum Islam, Implementasinya pada Periode Negara Madinah dan Masa Kini. Cet.1. Bogor: Kencana, 2003.

Tahir Azhary. Beberapa Aspek Hukum Tata Negara, Hukum Pidana dan Hukum Islam. Bogor: Kecana, 2012.

Rifyal Ka'bah. Hukum Islam di Indonesia. Jakarta: Universitas Yarsi, 1999.

Qodri Azizy. Eksistensi Hukum Nasional: Kompetisi antara Hukum Islam dan Hukum Umum. Yogyakarta: Gama Media Offset, 2004.

Yusril Ihza Mahendra. Dinamika Tata Negara Indonesia, Cet.1. Jakarta: Gema Insani Press, 1996. 